\title{
Nonlinear models in the study of the cedar diametric growth in a seasonally dry tropical forest
}

\author{
Ariana Campos Frühauf ${ }^{1} \oplus$, Gabriel de Assis Pereira ${ }^{2,3}{ }^{\oplus}$, Ana Carolina Maioli Campos Barbosa ${ }^{3} \oplus$, \\ Tales Jesus Fernandes ${ }^{1} \mathbb{D}$, Joel Augusto Muniz ${ }^{1}$

\footnotetext{
1 Universidade Federal de Lavras, Departamento de Estatística, Lavras, MG, Brasil. E-mail: arianafruhauf@gmail.com; tales.jernandes@ufla.br; joamuniz@ufla.br

2 Universidade de São Paulo, Escola Superior de Agricultura Luiz de Queiroz, Departamento de Ciências Florestais, Piracicaba, SP, Brasil. E-mail: gabriel_assispereira@hotmail.com

${ }^{3}$ Universidade Federal de Lavras, Departamento de Ciências Florestais, Lavras, MG, Brasil. E-mail: anabarbosa@ufla.br
}

ABSTRACT: The continuous decrease of forest cover in Brazil and the growing environmental pressure on forest-originate products increase the concern with the protection of the native forests remnants and endangered species such as the cedar (Cedrela fissilis Vell.), which has great economic prominence in the country due to the its excellent wood quality. Therefore, studying in detail its growth as a basis for its sustainable management in the forests is necessary. Based on the knowledge that nonlinear models are traditionally well fit for biological processes, this study aimed to compare the performance of the Brody, Gompertz, Logistic and von Bertalanffy models in reconstructing the cedar diametric growth. To that end, we used data from the mean diameter at breast height accumulated over time, obtained from non-destructive samples of 85 trees in an environmental preservation area. The models were fit using the $\mathrm{R}$ software considering the autoregressive error structure as of first order. All models demonstrated a good fit, although the Brody model was the best to describe the diametric growth of cedar over time in the studied region.

\section{Modelos não lineares no estudo do crescimento diamétrico de cedro em floresta tropical sazonalmente seca}

RESUMO: A redução contínua da cobertura florestal no país e a crescente pressão ambiental sobre os produtos de origem florestal aumentam a preocupação com a proteção dos remanescentes de florestas nativas e das espécies ameaçadas de extinção como o cedro (Cedrela fissilis Vell.), o qual tem grande destaque econômico no Brasil devido a excelente qualidade da sua madeira. Sendo assim, faz-se necessário o estudo detalhado do seu crescimento como base para seu manejo sustentável nas florestas que o contém. Partindo do conhecimento de que os modelos não lineares são tradicionalmente bem ajustados para processos biológicos, o objetivo deste estudo foi comparar o desempenho dos modelos Brody, Gompertz, Logístico e von Bertalanffy para reconstruir o crescimento diamétrico do cedro. Para isso, foram utilizados os dados do diâmetro à altura do peito médio acumulado ao longo do tempo, obtidos de amostras não destrutivas de 85 árvores em área de preservação ambiental. $\mathrm{O}$ ajuste dos modelos foi feito através do software $\mathrm{R}$ considerando-se a estrutura de erros autorregressivos de primeira ordem. Todos os modelos apresentaram bons ajustes, porém o modelo Brody apresentou-se como o melhor para descrever o crescimento diamétrico de cedro ao longo do tempo na região de estudo.

Palavras-chave: erros autocorrelacionados; Cedrela fissilis; curva de crescimento; anéis de crescimento; regressão não linear 


\section{Introduction}

The loss of forests is something rather considerable in Brazil, hence, it is possible observing the importance of sustainable forest management practices so that forest resources are perpetuated, since as according to Hess et al. (2018), nonintervention does not guarantee forest conservation; quite the contrary, it contributes to growth stagnation and low natural regeneration rate. The preservation of native forests is something of concern, since forestry research has been strongly focused on planted forests; few studies have been developed for natural forests, which present several tree species at risk of extinction (Martinelli \& Moraes, 2013).

Among these species is Cedrela fissilis Vell. (Cedar), with a wide distribution over Brazil, occurring more frequent in the southern and southeastern areas (CNCFlora, 2020). Cedar is among the woods of greater economic interest in the country due to its high wood quality and the color similar to mahogany. Cedar wood is widely used in civil, naval and aeronautical constructions, carpentry, furniture, musical and religious instruments, sculptures and even in popular medicine to combat fever, wounds and ulcers (Motta et al., 2014). Cedar is also used in recovering degraded areas due to its relatively fast growth (Cherobini et al., 2008).

Furthermore, species from the genus Cedrela show great potential for dendrochronological studies in the neotropics. They are deciduous trees during the dry season, reducing their cambium activity and thus leading to the formation of welldefined annual rings, which in turn provide important data on the rainfall seasonality in that forest and, consequently, the growth cycle of the trees (Granato-Souza et al., 2018; Pereira et al., 2018). These annual rings, therefore, record the tree growth in each climatic year (reflecting the annual rainfall seasonality), thus providing an accurate record of growth in diameter from the pith to the bark (Barbosa et al., 2018). Retrieving this information enables knowing the cedar growth patterns by age in native forests, contributing to the sustainable management plans and estimates of the carbon sequestration.

Analyzing the growth pattern in forest studies is usually by regression models means. Some authors found a sigmoid behavior in the growth of trees, leading them to employ nonlinear regression models (Ribeiro et al., 2017; Barbosa et al., 2018). In this case, these models are more appropriate than the linear ones in describing the biological processes, since they are generally more parsimonious and have parameters with practical interpretations (Sousa et al., 2014; Archontoulis \& Miguez, 2015).

In light of the foregoing, this study aims to model the diametric growth of cedar (Cedrela fissilis) according to age, from the measurements of its annual growth rings using nondestructive samples taken from native forest located in the far north of Minas Gerais. According to Marcon et al. (2019), there are only few studies on how are the growth patterns of trees in the Brazilian tropical and subtropical forests. The hypothesis that guides this study is that the radial growth of
Cedrela fissilis species has a direct relation with its age and can be described by nonlinear models.

\section{Materials and Methods}

The used data is from the permanent collection of the Dendroecology Laboratory from the Department of Forest Sciences (DCF) of the Federal University of Lavras (UFLA), municipality of Lavras/MG.

In the developing of this study, 85 native cedar trees chosen by a census sampling of the Cedrela fissilis population were used in areas of environmental preservation located in the municipality of Juvenília, far north of Minas Gerais (latitude $14.50^{\circ} \mathrm{S}$ and longitude $44.17^{\circ} \mathrm{W}$ ), in a preserved fragment of seasonally dry tropical forest. According to the nearest weather station (Carinhanha Station-BA, ID: 83408), the total annual precipitation in the region is $814 \mathrm{~mm}$, with the rainy season in the period from October to March, when approximately $90 \%$ of this precipitation occurs. The driest months are June, July and August, with average precipitation below $7 \mathrm{~mm}$ in these three altogether. Average monthly temperatures range from $22.4{ }^{\circ} \mathrm{C}$ to $26.4{ }^{\circ} \mathrm{C}$, with maximum monthly temperatures between $29.8{ }^{\circ} \mathrm{C}$ and $32.8{ }^{\circ} \mathrm{C}$ and minimum monthly temperatures between $15.3^{\circ} \mathrm{C}$ and $21.1^{\circ} \mathrm{C}$ (Barbosa et al., 2018; Pereira et al., 2018).

The collection took place in February and May 2016. Employing a non-destructive technique, thus not compromising the survival of sampled individuals, the selected samples were those that reached the tree pith. The rays of the sampled trees were extracted by using an increment borer (5.15 $\mathrm{mm}$ in diameter and $400 \mathrm{~mm}$ in length) at breast height $(1.30 \mathrm{~m})$. In the case of collecting more than two rays from the same tree, these were ensured to be diametrically opposites.

Radial wood samples were dried at room temperature, fixed on wooden supports and polished with a successive sequence of abrasive files to enable a clear visualization of the wood macroscopic structure by following standard dendrochronological procedures (Stokes \& Smiley, 1996).

Growth rings were identified with the aid of a stereomicroscopic magnifying glass, with their widths measured using the LINTAB-6 Scientific digital measurement system (Rinntech, 2019), boasting an accuracy of 0.001 $\mathrm{mm}$. For each sample, the sum of the widths of all rings is equivalent to the tree radius, with the double of that measurement resulting in the diameter at breast height (DBH) of that sampled tree.

Once the data, age and accumulated DBH of the 85 trees were obtained, the frequency distribution by age classes was constructed (Table 1); the data were grouped using 13 classes, where the length of each class equaled 12 years.

According to Fernandes et al. (2014), the most used nonlinear regression models when studying growth curves are the following: Brody (Equation 1), Gompertz (Equation 2), Logistic (Equation 3) and von Bertalanffy (Equation 4), which have its functional form displayed in Table 2 and were fit for the mean accumulated DBH $(\mathrm{cm})$ according to the average age of each class (years). Ribeiro et al. (2018a), Fernandes et al. 
Table 1. Frequency distribution by age class from mean accumulated diameter to breast height $(\mathrm{DBH})$ to describe the diametric growth of cedar (Cedrela fissilis).

\begin{tabular}{cccc}
\hline $\begin{array}{c}\text { Imin }^{\mathbf{1}} \\
\text { (years) }\end{array}$ & $\begin{array}{c}\text { Imax } \\
\text { (years) }\end{array}$ & $\begin{array}{c}\text { Maximum age of } \\
\text { the class (years) }\end{array}$ & $\begin{array}{c}\text { Accumulated } \\
\text { mean DBH }(\mathbf{c m})\end{array}$ \\
\hline 0 & 12 & 6 & 3.08 \\
12 & 24 & 18 & 8.59 \\
24 & 36 & 30 & 13.31 \\
36 & 48 & 42 & 17.80 \\
48 & 60 & 54 & 21.83 \\
60 & 72 & 66 & 25.36 \\
72 & 84 & 78 & 27.32 \\
84 & 96 & 90 & 28.59 \\
96 & 108 & 102 & 30.94 \\
108 & 120 & 114 & 34.92 \\
120 & 132 & 126 & 38.33 \\
132 & 144 & 138 & 41.51 \\
144 & 156 & 150 & 42.44 \\
\hline
\end{tabular}

${ }^{1}$ Minimum age of the class; ${ }^{2}$ maximum age of the class.

Table 2. Nonlinear models used to fit the mean accumulated $\mathrm{DBH}(\mathrm{cm})$ as a function of the average age (years) of cedar (Cedrela fissilis) and their respective inflection points.

\begin{tabular}{ccc}
\hline Equation & Functional Form & Inflection Point (IP) \\
\hline (1) & $y_{\mathrm{i}}=\alpha\left(1-\beta \cdot \mathrm{e}^{\left(-\kappa \mathrm{x}_{\mathrm{i}}\right)}\right)+\varepsilon_{\mathrm{i}}$ & Does not have \\
(2) & $\mathrm{y}_{\mathrm{i}}=\alpha \cdot \mathrm{e}^{-\mathrm{e}^{\kappa\left(\left(\beta-\mathrm{x}_{\mathrm{i}}\right)\right.}+\varepsilon_{\mathrm{i}}}$ & $\mathrm{IP}\left(\hat{\beta}, \frac{\hat{\alpha}}{\mathrm{e}}\right)$ \\
(3) & $\mathrm{y}_{\mathrm{i}}=\frac{\alpha}{1+\mathrm{e}^{\kappa\left(\beta-\mathrm{x}_{\mathrm{i}}\right)}+\varepsilon_{\mathrm{i}}}$ & $\mathrm{IP}\left(\hat{\beta}, \frac{\hat{\alpha}}{2}\right)$ \\
(4) & $\mathrm{y}_{\mathrm{i}}=\alpha\left(1-\mathrm{e}^{\frac{\kappa\left(\beta-\mathrm{x}_{\mathrm{i}}\right)}{3}}\right)^{3}+\varepsilon_{\mathrm{i}}$ & $\mathbb{I P}\left(\hat{\beta}, \frac{8}{27} \hat{\alpha}\right)$ \\
\hline
\end{tabular}

(2015), Fernandes et al. (2017) and Fernandes et al. (2019), respectively, suggested the parameterizations used.

In Equations 1, 2, 3 and 4, $y_{i}$ represents the i-th observation of the mean accumulated $\mathrm{DBH}$ in $\mathrm{cm}$, with i ranging from 1 to $13 ; x_{i}$ stands for the average age of the trees, in years; $\alpha$ is the asymptotic value, that is, the expected value for the maximum mean accumulated $\mathrm{DBH} ; \beta$ is related to the curve shape, corresponding to the inflection point abscissa for the Gompertz, Logistical and von Bertalanffy models and, without practical interpretation for the Brody model, whose curve has no sigmoidal shape; $\mathrm{k}$ is the index of maturity or precocity, which higher values indicates the less time the tree needs to reach its asymptotic size; and $\varepsilon_{i}$ is the random error, assumed to have normal distribution, constant variance and be independent, that is, $\varepsilon_{i} \sim N\left(0, \sigma^{2}\right)$.

Based on the first derivative of the model equations, the inflection point of the fitted sigmoid models can be graphically analyzed, thus allowing verifying the moment when the growth of the studied object decelerates, that is, when the instantaneous growth rate changes from increasing to decreasing, thus coinciding with the change in curve concavity. At this point, namely the inflection point, the first derivate curve reaches zero.

Finding the inflection point for each fitted model is possible based on the parameter estimates (Table 2). Thereby, the Logistic model is symmetrical in relation to this point, as it occurs exactly during the middle of the maximum development of the mean accumulated $\mathrm{DBH}$; whereas the Gompertz model, $\mathrm{e} \approx 2.7182$, reaches this $\alpha$ point at approximately $37 \%$ maximum development, that is, before the middle; and the von Bertalanffy model, even earlier, reaches approximately $30 \%$ of the asymptotic value (Fernandes et al., 2014; Ribeiro et al., 2018a).

In order to estimate the model parameters, the least squares method was applied. The Gauss-Newton convergence algorithm was used as an iterative method and the significance of the parameters verified by the Student $t$ test, with $v=n-$ $p$ degrees of freedom, with $n$ as the number of observations and $p$ the number of model parameters, seen in Ribeiro et al. (2018b) and Jane et al. (2019).

After fitting the models, the assumptions of residual homoscedasticity, normality and independence were all verified through the Breusch-Pagan, Shapiro-Wilk and DurbinWatson tests, respectively, at the level of $1 \%$ significance. A visual analysis of the residuals through graphical distribution and residual histogram was also performed. According to Fernandes et al. (2014), in order to obtain an adequate fitting through regression models, it is extremely important validating the assumptions; otherwise, the model is deemed as inadequate.

After verifying the residual dependence, the parameters were estimated by using the generalized minimum squares method, incorporating the autoregressive parameter of the order $p$ to the residual, described by (Equation 5 ):

$$
\mathrm{u}_{\mathrm{i}}=\phi_{1} \mathrm{u}_{\mathrm{i}-1}+\ldots+\phi_{\mathrm{p}} \mathrm{u}_{\mathrm{i}-\mathrm{p}}+\varepsilon_{\mathrm{i}}
$$

in which: $\mathrm{i}=1,2, \ldots, \mathrm{n}$ with $\mathrm{n}$ as the number of times that growth was measured; $u_{i}$ is the fitting residual in the $i$-th time; $\phi_{1}$ is the autoregressive parameter of order $1 ; u_{i-1}$ is the time fitting residual immediately before the i-th measurement; $\phi_{p}$ is the autoregressive parameter of order $p ; u_{i-p}$ is the fitting residual in $p$ times before the $i$-th measurement; and $\varepsilon_{i}$ is the white noise, with normal distribution $N\left(0, \sigma^{2}\right)$. For the particular case of AR (1) first order, there is $u_{i}=\phi_{1} u_{i-1}+\varepsilon_{i}$ (Ribeiro et al., 2018b).

The models parameters were estimated, with the comparison and model selection that best described the data made based on the results found for the corrected fitting index (Equation 6), the corrected Akaike information criterion (Equation 7), and the standard deviation residual (Equation 8):

$$
\begin{gathered}
\mathrm{IA}_{\mathrm{c}}=1-(1-\mathrm{IA})\left[\frac{(\mathrm{n}-1)}{\mathrm{n}-\mathrm{p}}\right] \\
\mathrm{AIC}_{\mathrm{c}}=\mathrm{n} \ln \left(\frac{\mathrm{SQR}}{\mathrm{n}}\right)+\frac{2 \mathrm{p}(\mathrm{p}+1)}{\mathrm{n}-\mathrm{p}-1} \\
\mathrm{DPR}=\sqrt{\mathrm{QME}}
\end{gathered}
$$


in which: IA is the fitting index; SQR represents the sum of squares of the residuals; $n$ the number of observations, $p$ is the number of parameters of the fit model, and QME is the residual mean square. The best-fitted model is the one with the highest $I A_{c}$ and lowest values for the $A I C_{C}$ and DPR.

The estimation of the model parameters, as well as the graphic fittings and all the computational part of this research were done employing the R statistical software (R Core Team, 2020), by using the packages "nlme", "car", "Imtest" e "qpcR".

\section{Results and Discussion}

After fitting the Brody, Gompertz, Logistical and von Bertalanffy models to the mean accumulated DBH data as function to the age of the cedar trees, we conducted an analysis with the residual vector. Through the Shapiro-Wilk and Breusch-Pagan tests, the presuppositions of normality and homogeneity of the required variances were met $(p>$ 0.01 ) in all fit models, indicating that the residuals vector is normally distributed and has constant variance.

Contrary, through the Durbin-Watson test, the presence of residual autocorrelation $(p<0.01)$ was verified for all fit models. This was expected since the data for each tree was not from the same tree over time only, but also from the same

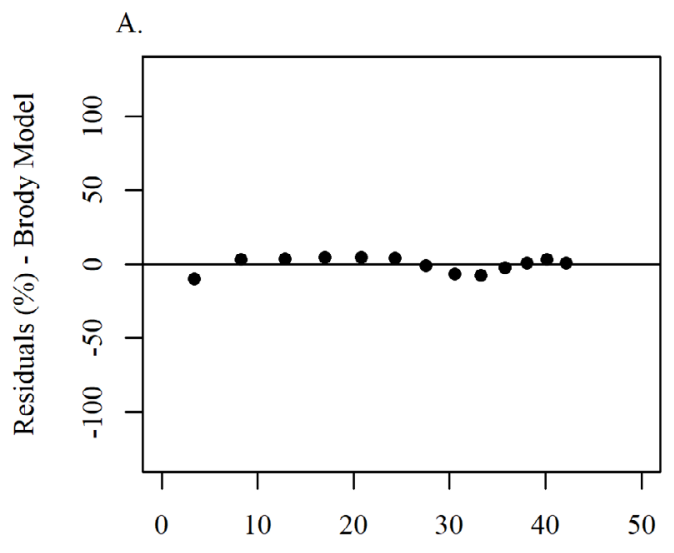

Fitted Values

$$
\text { C. }
$$

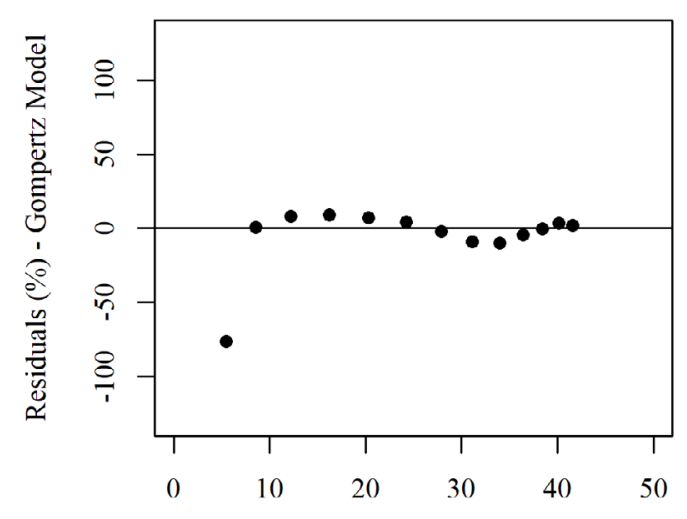

Fitted Values sample as it is obtained by dendrochronological techniques, thus corroborating Cassiano \& Sáfadi (2015), who state that observations classified over time and performed on the same individual are generally autocorrelated.

In view of the residual dependence, the fitting was made once again by the generalized least squares method, incorporating the first order autoregressive parameter to the models. $\left(\phi_{1}\right)$, because according to Ribeiro et al. (2018b), in presence of autocorrelated errors, it is important to model this autocorrelation and incorporate it into the model to ensure greater precision in the estimates. Muianga et al. (2016), Muniz et al. (2017), Silva et al. (2020) and Jane et al. (2020) all found similar results when observing autocorrelated errors in the fitting of nonlinear models applied to the growth data in cashew, cacao, blackberry and sugar cane varieties, respectively.

After incorporating the first order autoregressive parameter $\left(\phi_{1}\right)$ to the models, a new residual analysis was made and all the assumptions associated with the errors of the fit models were validated, at the level of $1 \%$ significance, indicating that the estimates obtained are reliable and the inferences are valid.

Figures 1, 2 and 3 demonstrate that the graphical distribution and the histogram of the percentage residuals for the Brody, Gompertz, Logistical and von Bertalanffy models, with the incorporation of the autoregressive parameter (AR1)

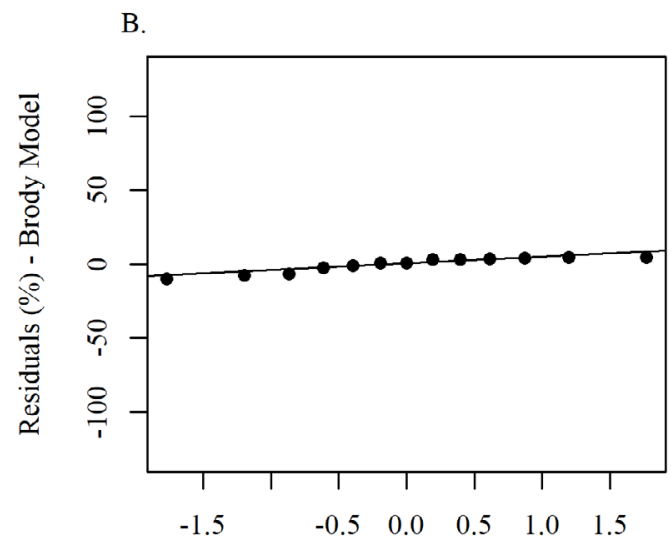

Theorical quantile

D.

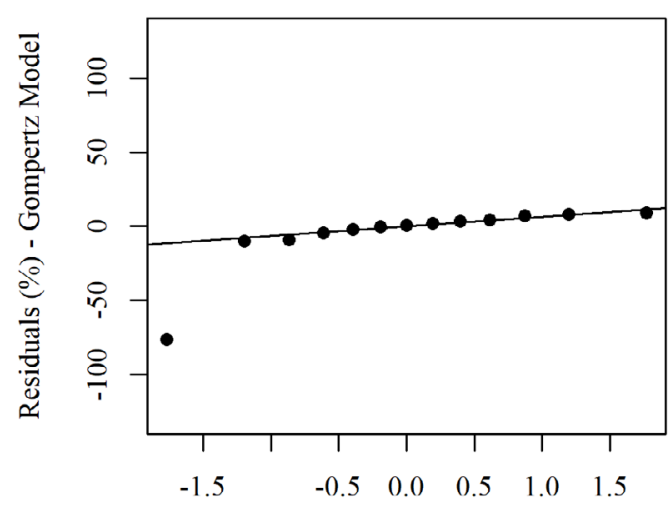

Theorical quantile

Figure 1. Graphical distribution of percentage residuals for the mean accumulated DBH (cm) of cedar trees (Cedrela fissilis), in which $(A)$ and $(C)$ represent the fit values in relation to the percentage residuals while (B) and (D) are in relation to theoretical quantiles for the Brody and Gompertz models with AR1. 


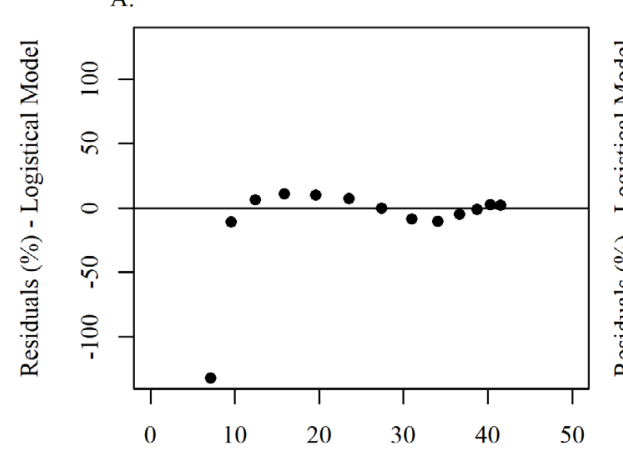

Fitted Values

C.

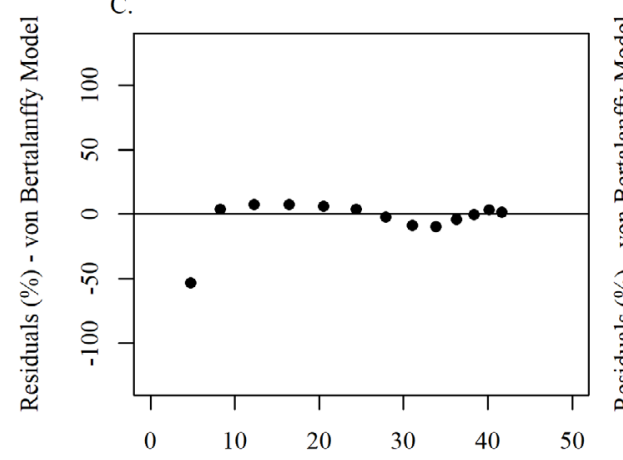

Fitted Values
B.

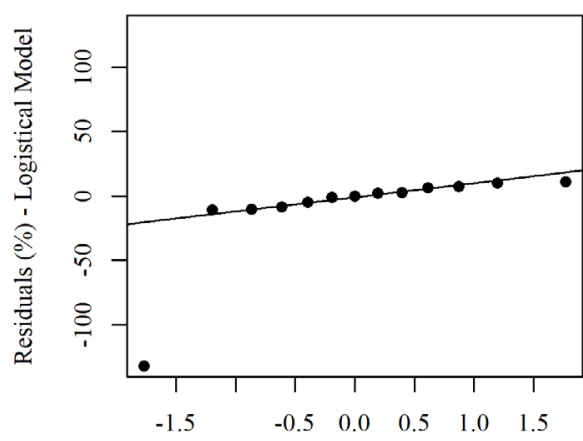

Theorical quantile

D.

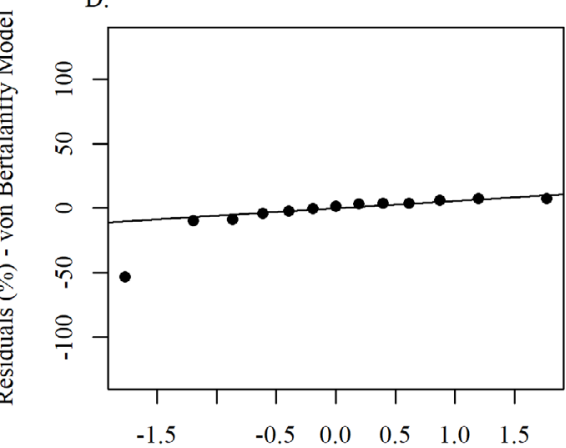

Theorical quantile

Figure 2. Graphical distribution of percentage residuals for the mean accumulated $\mathrm{DBH}(\mathrm{cm})$ of cedar trees (Cedrela fissilis), in which (A) and (C) represent the fit values in relation to the percentage residuals while (B) and (D) are in relation to theoretical quantiles for the Logistical and von Bertalanffy models with AR1.
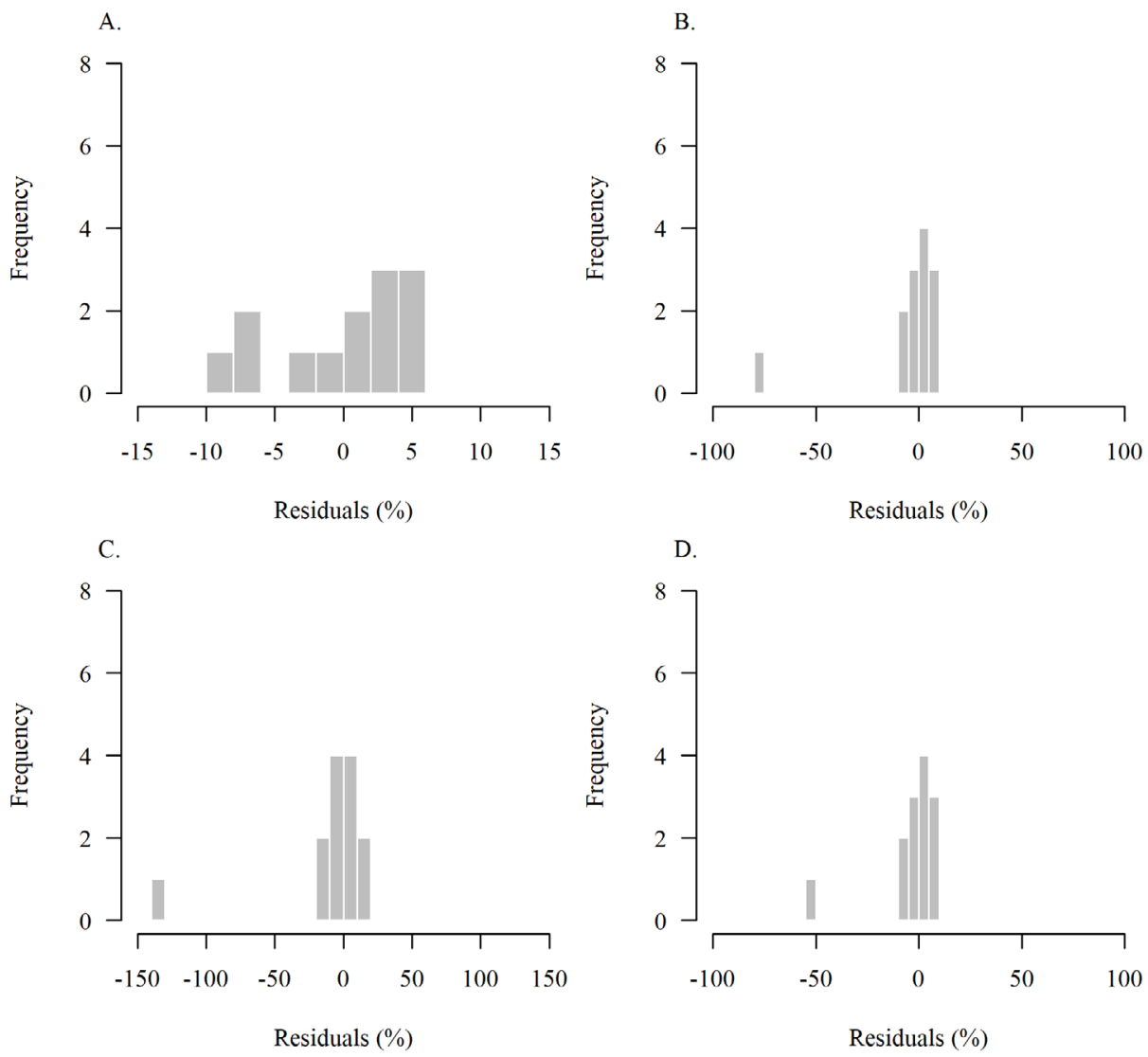

Figure 3. Percentage residuals histogram for the fitting of Brody (A), Gompertz (B), Logistical (C) and von Bertalanffy (D) models with the incorporation of the first order autoregressive parameter (AR1). 
for all data of mean accumulated $\mathrm{DBH}(\mathrm{cm})$ of cedar trees (Cedrela fissilis), corroborate the results obtained with the Shapiro-Wilk and Breusch-Pagan tests, showing normality and homogeneity in the residuals.

Table 3 illustrates the estimates of the parameters and their respective confidence intervals of $95 \%$ probability, based on the fitting of the Brody, Gompertz, Logistical and von Bertalanffy models, for the mean average DBH $(\mathrm{cm})$ measurements of cedar trees (Cedrela fissilis) considering the structure of first order autoregressive errors. All estimated parameters were significant, by the test, at $1 \%$ significance.

By observing the results in Table 3, we see the parameters of the evaluated models are not null since the confidence intervals do not include zero, thus indicating quality in their estimation. The estimates of the $\alpha$ parameter were very close for the Gompertz, Logistical and von Bertalanffy models, whereas the Brody model presented a value above the others, which can also be found in the studies conducted by Oliveira et al. (2000) and Ribeiro et al. (2017).
Cedar can have a DBH between 40 and $80 \mathrm{~cm}$, according to Carvalho (2003), agreeing with this study, in which cedars in their senile phase, around 150 years old, presented an asymptotic value $(\alpha)$ for the mean accumulated DBH within the time interval abovementioned for all fit models, indicating good fittings. On the other hand, the estimates disagreed with the DBH values cited by Silva (2013) and by Coradin et al. (2011). These authors indicated values between 60 and $150 \mathrm{~cm}$, which can be justified by the seasonally dry region in which the sampled trees are located, since according to Pereira et al. (2018), the local rainfall index directly interferes with tree growth in the tropics.

The differences found in the parameter value are associated with the sigmoidal shape of different curves from fit models, which was also verified by Fernandes et al. (2014) and Ribeiro et al. (2018b).

By analyzing the curves of the first derivative of the models fit for age (Figure 4), it is possible observing the growth rates of the studied species. In Figures 4 A, B, C and D, the maximum

Table 3. Estimates for the parameters and their respective Confidence Intervals (LL; UL) based on the fittings of the Brody, Gompertz, Logistical and von Bertalanffy models for the mean accumulated DBH (cm) measurements of cedar trees (Cedrela fissilis) considering the structure of first order autoregressive errors (AR1).

\begin{tabular}{|c|c|c|c|c|}
\hline Estimates & $\alpha$ & $\beta$ & $\kappa$ & $\phi_{1}$ \\
\hline Brody & 64.37 & 0.99 & 0.007 & 0.60 \\
\hline $\mathrm{Cl}$ & $(43.16 ; 85.58)$ & $(0.94 ; 1.03)$ & $(0.003 ; 0.011)$ & $(0.08 ; 0.86)$ \\
\hline Gompertz & 47.30 & 45.43 & 0.020 & 0.67 \\
\hline Logistical & 44.65 & 62.31 & 0.029 & 0.71 \\
\hline $\mathrm{Cl}$ & $(35.53 ; 53.77)$ & $(40.72 ; 83.90)$ & $(0.016 ; 0.043)$ & $(0.02 ; 0.94)$ \\
\hline
\end{tabular}
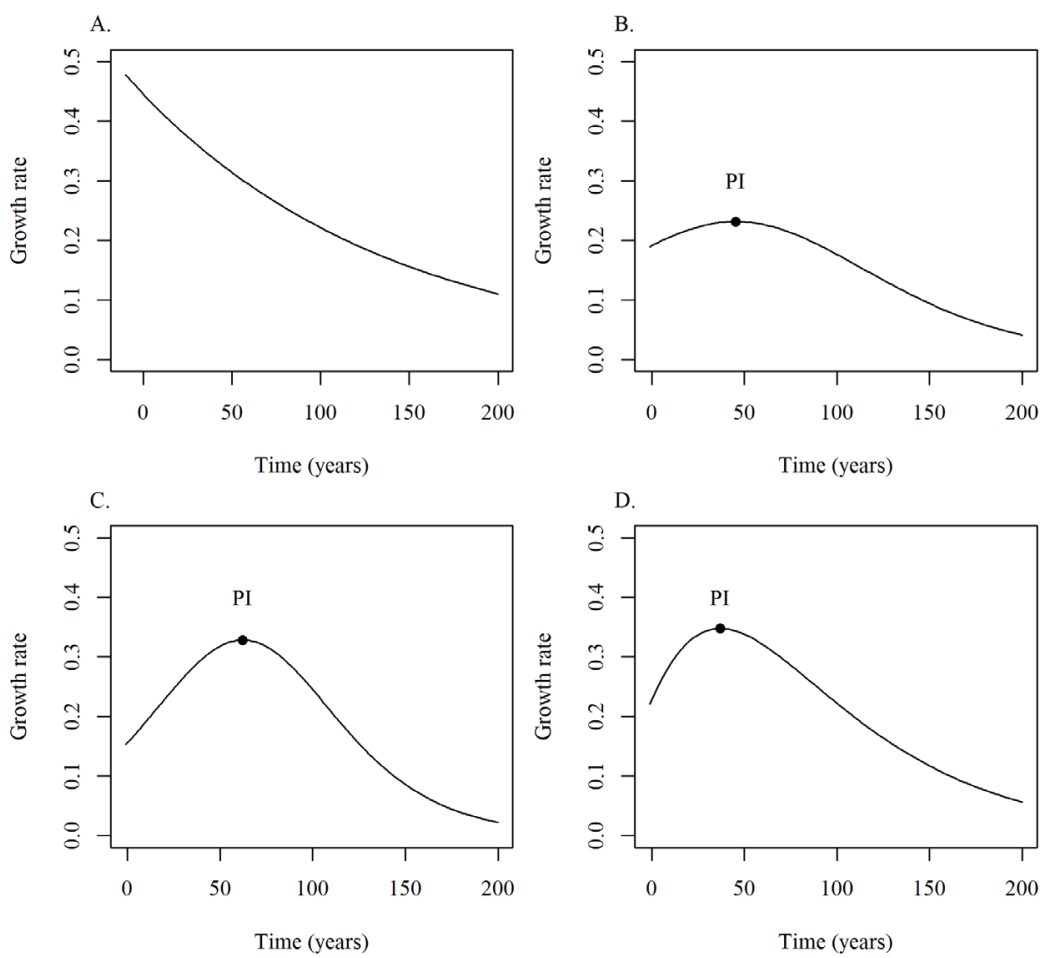

Figure 4. Graphs of growth rates in mean accumulated DBH of cedar obtained through the first derivative of the Brody (A), Gompertz (B), Logistical (C) and von Bertalanffy models (D). 
point indicates the inflection point (IP) of the curve for fit models, which coincide with those verified by the estimates of $\beta$. Thereby, we verified that the maximum development of the mean accumulated DBH was around 37, 45 and 62-yearsold for the von Bertalanffy, Gompertz and Logistical models respectively, with a mean accumulated $\mathrm{DBH}$ of approximately 15, 17 and $22 \mathrm{~cm}$ for these same models. Each model had different ages for the inflection point, with the exception of the Brody model, which does not have this point, with the Logistics model as the most different from the others, aged 62 years. For the von Bertalanffy and Gompertz models, we concluded that the growth of the cedar starts to decelerate when it is 37 and 45-years-old, respectively, which are values consistent with the expected for the species in the semiarid region. While this information needs to be yet further explored, it already demonstrates the data potential for the careful planning of cutting cycles and the necessary care in the correct model choice, starting from a more conservationist or productive viewpoint.

In Table 4, all models indicated a good fit to the data. However, as the Brody model had the lowest values for DPR and $\mathrm{AIC}_{\mathrm{C}^{\prime}}$ and the highest value for $\mathrm{IA}_{\mathrm{c}^{\prime}}$ it is suggested that it is model that best describes the data.

Figure 5 illustrates the fitting graphs of the Brody, Gompertz, Logistical and von Bertalanffy models with first order autoregressive errors (AR1) structure to the data of the mean accumulated DBH $(\mathrm{cm})$. The visual analysis indicates that the models fit well to the data of the mean accumulated DBH of the trees, with emphasis on the Brody model, which was closer to the observed values. The Gompertz, Logistical and von Bertalanffy models overestimated the initial the final values, something that did not happen with the Brody model.

Based on the criteria used to evaluate the fit quality and the visual data analysis, all the fit models were adequate to describe the diametric growth of cedar (Cedrela fissilis) in the studied region. However, the Brody model had a higher $I A_{C}$ value, lower values for $\mathrm{AIC}_{C}$ and DPR, and curve closer to the observed values, hence considered as the model that best described the studied data.

The database provided by the annual tree growth rings allows obtaining accurate information on the individual growth of the population of same-species trees. In the cedar case, a species threatened with extinction yet of great commercial appeal in the timber sector, the recovery of growth by age in native stands and constructing growth curves in a non-

Table 4. Criteria for assessing the fitting quality of the Brody, Gompertz, Logistical and von Bertalanffy models with first order autoregressive error structure (AR1).

\begin{tabular}{cccc}
\hline Model & DPR & AIC $_{c}$ & IA $_{c}$ \\
\hline Brody & 1.1778 & 45.0772 & 0.9903 \\
Gompertz & 1.8575 & 55.1552 & 0.9781 \\
Logistical & 2.4398 & 60.8443 & 0.9669 \\
von Bertalanffy & 1.6371 & 52.2267 & 0.9822 \\
\hline
\end{tabular}

$\mathrm{DPR}=$ residual standard deviation; $\mathrm{AIC}_{\mathrm{c}}=$ corrected Akaike infromation criterion; $\mathrm{IA}=$ corrected fitting index.

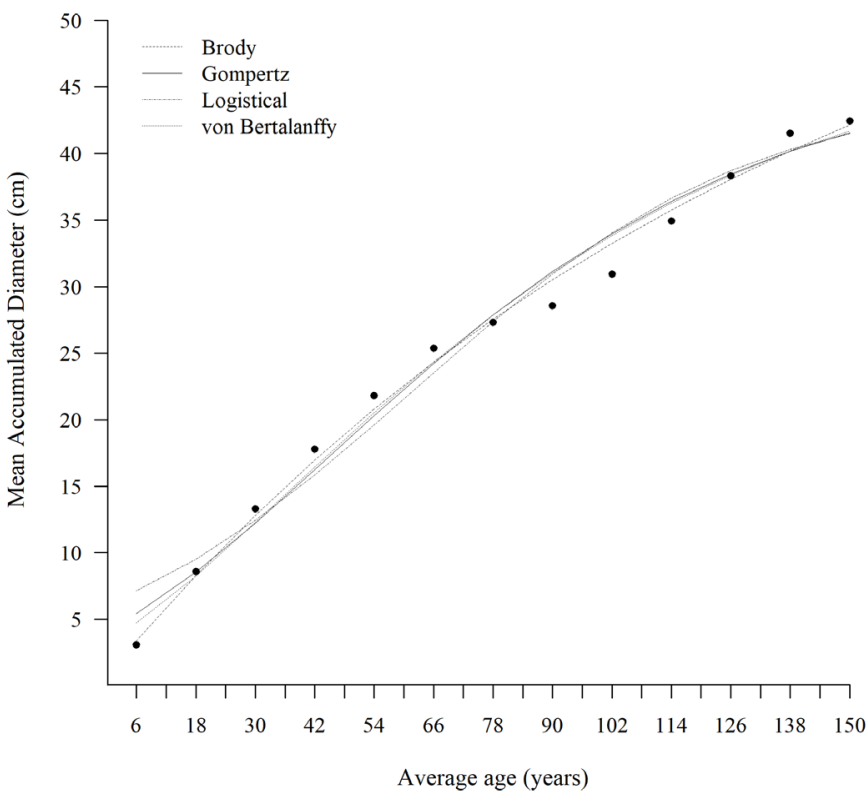

Figure 5. Fittings of the Brody, Gompertz, Logistical and von Bertalanffy models to the data of the mean accumulated DBH $(\mathrm{cm})$ of cedar trees (Cedrela fissilis) with first order autoregressive error structure (AR1).

destructive way, allows access to fundamental data for planning the sustainable management in its own areas.

The proper modeling of cedar growth in several areas of its wide geographic occurrence in Brazil may help in the mapping of promising regions for its commercial planting or enrichment of the species in fragments of native forests.

\section{Conclusions}

The tested nonlinear models were adequate to describe the growth of cedar (Cedrela fissilis) grouped in age classes, however, the Brody model was the one that best adhered to the data.

Due to the presence of residual autocorrelation, the first order autoregressive parameter $\left(\phi_{1}\right)$ was included, which ensured greater precision in the estimates.

\section{Acknowledgements}

To the Coordination for the Improvement of Higher Education Personnel (CAPES) and to the Brazilian National Council for Scientific and Technological Development (CNPq) for the granted scholarships. To the Minas Gerais Research Funding Foundation (FAPEMIG), Project APQ 02541-14.

To the nonlinear regression study nucleus (NLIN) of the Federal University of Lavras (UFLA).

\section{Literature Cited}

Archontoulis, S.V.; Miguez, F.E. Nonlinear regression models and applications in agricultural research. Agronomy Journal, v.107, n.2, p.786-798, 2015. https://doi.org/10.2134/agronj2012.0506. 
Barbosa, A.C.M.; Pereira, G.A.; Granato-Souza, D.; Santos, R.M.; Fontes, M.A.L. Tree rings and growth trajectories of tree species from seasonally dry tropical forest. Australian Journal of Botany, v.66, n.5, p.414-427, 2018. https://doi.org/10.1071/BT17212.

Carvalho, P.E.R. Espécies arbóreas brasileiras. Brasília: Embrapa Informação Tecnológica; Colombo: Embrapa Florestas, 2003. $1039 \mathrm{p}$.

Cassiano, F.R.; Sáfadi, T. Modelos de crescimento animal para tempos irregulares. Pesquisa Agropecuária Brasileira, v.50, n.11, p.1114-1119, 2015. https://doi.org/10.1590/S0100204X2015001100015.

Centro Nacional de Conservação da Flora - CNCFlora. Cedrela fissilis in Lista Vermelha da flora brasileira versão 2012.2. http://cncflora. jbrj.gov.br/portal/pt-br/profile/Cedrela\%20fissilis . 06 Jun. 2020.

Cherobini, E.A.I.; Muniz, M.F.B.; Blume, E. Avaliação da qualidade de sementes e mudas de cedro. Ciência Florestal, v.18, n.1, p.65-73, 2008. https://doi.org/10.5902/19805098511.

Coradin, L.; Siminski, A.; Reis, A. Espécies nativas da flora brasileira de valor econômico atual ou potencial: plantas para o futuro Região Sul. Brasília: MMA, 2011. 934 p.

Fernandes, F.A.; Fernandes, T.J.; Pereira, A.A.; Meirelles, S.L.C.; Costa, A.C. Growth curves of meat-producing mammals by von Bertalanffy's model. Pesquisa Agropecuária Brasileira, v.54, e01162, 2019. https://doi.org/10.1590/s1678-3921.pab2019. v54.01162.

Fernandes, T.J.; Muniz, J.A.; Pereira, A.A.; Muniz, F.R.; Muianga, C.A. Parameterization effects in nonlinear models to describe growth curves. Acta Scientiarum. Technology, v.37, n.4, p.397-402, 2015. https://doi.org/10.4025/actascitechnol.v37i4.27855.

Fernandes, T.J.; Pereira, A.A.; Muniz, J.A. Double sigmoidal models describing the growth of coffee berries. Ciência Rural, v.47, n.8, e20160646, 2017. https://doi.org/10.1590/01038478 cr20160646.

Fernandes, T.J.; Pereira, A.A.; Muniz, J.A.; Savian, T.V. Seleção de modelos não lineares para a descrição das curvas de crescimento do fruto do cafeeiro. Coffee Science, v.9, n.2, p.207-215, 2014. http://www.sbicafe.ufv.br:80/handle/123456789/8029. 03 Feb. 2020.

Granato-Souza, D.; Stahle, D.W.; Barbosa, A.C.; Feng, S.; Torbenson, M.C.A.; Pereira, G.A.; Schöngart, J.; Barbosa, J.P.; Griffin, D. Tree rings and rainfall in the equatorial Amazon. Climate Dynamics, v.52, p.1857-1869, 2018. https://doi.org/10.1007/s00382-0184227-y.

Hess, A.F.; Ricken, P.; Ciarnoschi, L.D. Dendrocronologia, incremento e manejo florestal em floresta de araucária-SC. Ciência Florestal, v.28, n.4, p.1568-1582, 2018. https://doi. org/10.5902/1980509835104.

Jane, S.A.; Fernandes, F.A.; Silva, E.M.; Muniz, J.A.; Fernandes, T.J. Comparison of polynomial and nonlinear models on description of pepper growth. Revista Brasileira de Ciências Agrárias, v.14, n.4, e7180, 2019. https://doi.org/10.5039/agraria.v14i4a7180.

Jane, S.A.; Fernandes, F.A.; Silva, E.M.; Muniz, J.A.; Fernandes, T.J.; Pimentel, G.V. Adjusting the growth curve of sugarcane varieties using nonlinear models. Ciência Rural, v.50, n.3, e20190408, 2020. https://doi.org/10.1590/0103-8478cr20190408.
Marcon, A.K.; Longhi-Santos, T.; Botosso, P.C.; Blum, C.T.; Martins, K.G.; Galvão, F. Padrões de crescimento de Araucaria angustifolia e Cedrela fissilis in South center region of Paraná. BIOFIX Scientific Journal, v.4, n.2, p.116-123, 2019. https://doi.org/10.5380/biofix.v4i2.65321.

Martinelli, G.; Moraes, M.A. Livro vermelho da flora do Brasil. Rio de Janeiro: Instituto de Pesquisas Jardim Botânico do Rio de Janeiro, 2013. $1100 \mathrm{p}$.

Motta, J.P.; Oliveira, J.T.S.; Braz, R.L.; Duarte, A.P.C.; Alves, R.C. Caracterização da madeira de quatro espécies florestais. Ciência Rural, v.44, n.2, p.2186-2192, 2014. https://doi.org/10.1590/0103-8478cr20130479.

Muianga, C.A.; Muniz, J.A.; Nascimento, M.S.; Fernandes, T.J.; Savian, T.V. Descrição da curva de crescimento de frutos do cajueiro por modelos não lineares. Revista Brasileira de Fruticultura, v.38, n.1, p.22-32, 2016. https://doi.org/10.1590/0100-2945-295/14.

Muniz, J.A.; Nascimento, M.S.; Fernandes, T.J. Nonlinear models for description of cacao fruit growth with assumption violations. Revista Caatinga, v.30, n.1, p.250-257, 2017. https://doi.org/10.1590/198321252017v30n128rc.

Oliveira, H.N.; Lôbo, R.B., Pereira, C.S. Comparação de modelos nãolineares para descrever o crescimento de fêmeas da raça guzerá. Pesquisa Agropecuária Brasileira, v.35, n.9, p.1843-1851, 2000. https://doi.org/10.1590/S0100-204X2000000900017.

Pereira, G.A.; Barbosa, A.C.M.C.; Torbenson, M.C.A.; Stahle, D.W.; GranatoSouza, D.; Santos, R.M.; Barbosa, J.P.D. The Climate Response of Cedrela Fissilis annual ring width in the Rio São Francisco Basin, Brazil. Tree-Ring Research, v.74, n.2, p.162-171, 2018. https://doi. org/10.3959/1536-1098-74.2.162.

R Core Team. R: A language and environment for statistical computing. Vienna: R Foundation for Statistical Computing, 2020. https://www.rproject.org. 04 Mar. 2020.

Ribeiro, M.D.S.B.; Jorge, L.A.B.; Mischan, M.M.; Santos, A.L.; Ballarin, A.W. Avaliação da produção de biomassa do fuste de um clone híbrido de eucalipto sob diferentes espaçamentos. Ciência Florestal, v.27, n.1, p.31-45, 2017. https://doi.org/10.5902/1980509826445.

Ribeiro, T.D.; Mattos, R.W.P. de; Morais, A.R. de; Muniz, J.A. Description of the growth of pequi fruits by nonlinear models. Revista Brasileira de Fruticultura, v.40, n.4, e-949, 2018a. https://doi.org/10.1590/010029452018949.

Ribeiro, T.D.; Savian, T.V.; Fernandes, T.J.; Muniz, J.A. The use of the nonlinear models in the growth of pears of 'Shinseiki' cultivar. Ciência Rural, v.48, n.1, e20161097, 2018b. https://doi.org/10.1590/01038478cr20161097.

Rinntech. LINTAB: Precision - for every single tree ring. Heidelberg: Rinntech, 2019. http://www.rinntech.de/content/view/16/47/ lang,english/index.html. 08 Feb. 2020.

Silva, E.M. da; Tadeu, M.H.; Silva, V.F. da; Pio, R.; Fernandes, T.J.; Muniz, J.A. Description of blackberry fruit growth by nonlinear regression models. Revista Brasileira de Fruticultura, v.42, n.2, e-177, 2020. https://doi. org/10.1590/0100-29452020177.

Silva, S. Árvores nativas do Brasil. v.1. São Paulo: Editora Europa, 2013. $168 p$.

Sousa, I.F.; Kunzle Neto, J.E.; Muniz, J.A.; Guimarães, R.M.; Savian, T.V.; Muniz, F.R. Fitting nonlinear autoregressive models to describe coffee seed germination. Ciência Rural, v.44, n.11, p.2016-2021, 2014. https:/ doi.org/10.1590/0103-8478cr20131341.

Stokes, M.A.; Smiley, T.L. An introduction to tree-ring dating. Tucson: University of Arizona Press, 1996. 73p. 